\title{
Pathogenic bacteria in turkey meat: A review ${ }^{1}$
}

Bactérias patogênicas em carne de peru: uma revisão

\section{Higor Oliveira Silva ${ }^{2}$; Ana Maria Centola Vidal ${ }^{3}$; Oswaldo Durival Rossi Junior ${ }^{2}$}

Resumo: Apesar dos avanços alcançados com a adoção de programas de segurança e controle de alimentos, os sistemas de vigilância ainda relatam a ocorrência de doenças transmitidas por alimentos (DTAs) em países desenvolvidos e em desenvolvimento, e a carne de peru é frequentemente envolvida em surtos, atingindo várias pessoas anualmente. As bactérias são responsáveis por mais de $66 \%$ dos casos de DTAs que resultam em hospitalizações, destacando-se principalmente Salmonella spp., Campylobacter sp., Escherichia coli, Listeria monocytogenes, Staphylococcus spp., Clostridium botulinum e Clostridium perfringens. As fontes de contaminação de carcaças de peru são semelhantes às de frango, entretanto, os relatos sobre o envolvimento da carne de peru em DTAs e seu risco a saúde pública são escassos. Assim, esta revisão se concentrou em identificar os microorganismos relatados nos surtos de carne de peru e seus fatores de risco e nas principais fontes de contaminação, bem como as limitações no estudo de sua epidemiologia desde a produção até os consumidores. Um alto risco foi atribuído ao gênero Salmonella spp., Escherichia coli, Staphylococcus spp. e Campylobacter sp., sendo o último, considerado negligenciado nos países em desenvolvimento. Este estudo mostrou a necessidade de um maior incentivo às pesquisas sobre as condições sanitárias da carne de peru processada no Brasil, bem como a necessidade de monitorar esta carne vendida no país.

Palavras chave: Salmonella spp., Campylobacter sp., Escherichia coli, Listeria monocytogenes, Staphylococcus spp.

Abstract: Besides the advances in the adoption of programs regarding food safety and control, the surveillances system still have been reporting the occurrence of foodborne diseases (FBD) in developed and developing countries, and turkey meat is often involved in outbreaks affecting a large amount of human beings annually. Bacteria are responsible by more than $66 \%$ of cases of FBD resulting in hospitalizations and highlighting the importance of Salmonella spp., Campylobacter sp., Escherichia coli, Listeria monocytogenes, Staphylococcus spp., Clostridium botulinum and Clostridium perfringens. The contamination sources of turkey carcasses are similar to poultry, however; the reports regarding the involvement of turkey meat in FDB and its risk to public health is rare. Thus, this review focused on identify the microorganisms reported in turkey meat's outbreaks and their risk factors and mainly contamination sources, as well the limitations to study their epidemiology from farm to consumers. A high-risk was attributed to the genus Salmonella spp., Escherichia coli, Staphylococcus spp. and Campylobacter sp., and the latest is considered as neglected in developing countries. This study shown the need of a higher incentive to researches regarding the sanitary conditions of turkey meat processed in Brazil, as well as the need of monitoring this meat sold in the country.

Keywords: Salmonella spp., Campylobacter sp., Escherichia coli, Listeria monocytogenes, Staphylococcus spp.

Author for correspondence. E.Mail: *higorvet@yahoo.com.br

Recebido em 14.01.2017. Aceito em 30.09.2017 
Silva et al., Revista Brasileira de Higiene e Sanidade Animal (v.11, n.3) p. 338 - 353, jul - set (2017)

Review originated from master's dissertation

1. Doutorando Universidade Estadual Paulista (UNESP). E.Mail: higorvet@yahoo.com.br

2. Professor Doutor da Universidade de São Paulo (USP). E.Mail: anavidal@usp.br

3. Professor Doutor da Universidade Estadual Paulista (UNESP) E.Mail:rossijr@ fcav.unesp.br http://dx.doi.org/10.5935/1981-2965.20170034

\section{Introduction}

Turkey meat production has a high importance to Brazil due its economic potential, which is $7 \%$ of global production. Besides the Brazilian consumption is lower than the observed in the Unitade States of America, $1.7 \mathrm{~kg}$ against $45 \mathrm{~kg} /$ individual/year, the biggest portion (59\%) is sold in the internal market and $41 \%$ through export (ABPA, 2016) with a increasing expectative for 2017 (USDA, 2017).

From a long time it is known that besides the importance of food production and distribution by multinationals to international market, they also result in new risks for foodborne diseases (FD) transmission (KAFERSTEIN \& MORTAJEMI, 1997).

Thus, to improve its competitive potential is important that national production of turkey meat obtain the best standards quality (COSTA, 2006). The contamination sources to turkey carcasses are similar to poultry and it is considered as a risk to industries due the slaughter when there is several possibilities of contamination through processing (POPPE, 2000; ASLAM et al., 2004). To avoid the contamination of turkey meat is a challenge and the presence of pathogenic microorganisms in carcasses is a risk factor to consumer's health (REZENDE et al., 2005).

The programs of food safety need to offer a satisfactory control of quality from production to consumers because FD are a risk for public health (HAVELAAR, 2015; BRASIL, 2010; CAVALLI, 2001).

Besides the advances obtained though the adoption of programs regarding food safety and control, the FD are commonly reported. The countries with good surveillance systems as United States of America (USA) report that more than 9 million of human beings were affected by FD, and turkey meat was the category more frequent and responsible by $22 \%$ if 20,000 hospitalizations and $29 \%$ of 3890 deaths resulting from it (PAINTER, 2013; SCALLAN et al., 2011).

Across the time, the microorganisms involved in FB outbreaks were changed because pathogens which were not well established became to be controlled or eliminate due the emergence or recognizing of their potential as pathogenic microorganisms and global outbreaks of some pathogens transmitted by food, or also due the emergence of antimicrobial resistance (BEHRAVESH, 2012).

The bacteria are the most important in foodborne outbreaks and are responsible by $66 \%$, followed by chemical agents $(26 \%)$, virus (4\%) and parasites (4\%) (ADDIS \& SISAY, 2015). Bacterial FD occurs in three distinct ways: infection (when pathogens are consumed and establish on gastrointestinal tract), intoxication (occur due ingestion of food 
Silva et al., Revista Brasileira de Higiene e Sanidade Animal (v.11, n.3) p. 338 - 353, jul - set (2017)

containing toxins produced by pathogens), and toxi-infection (ingestion of pathogens that produce toxins at the gastrointestinal tract) (ADDIS \& SISAY, 2015; BRASIL, 2010; APHA, 2000).

Among bacterial FD, botulism, gastroenteritis by Clostridium perfringens, infections by Escherichia coli, Salmonella spp. and intoxications caused by Staphylococcus spp. are considered as important (ADDIS \& SISAY, 2015). However, the agency of public health from Agricultural Department of USA, also highlight Listeria monocytogenes and Campylobacter spp., in poultry meat (USDA, 2016).

There is a lack of information regarding the quality of turkey meat and its importance to public health (JOUKI 2012). Thus, the most important bacteria involved in FD outbreaks worldwide linked to turkey meat consumption and their importance to public health will be discussed in this review, regarding their epidemiology, prevalence, contamination sources, risk factors and antimicrobial resistance.

\section{Literature review}

\section{Salmonella spp.}

The genus Salmonella belong to the Enterobacteriaceae. They are bacillus, Gramnegative bacilli, mesophilic, facultative anaerobe and without spores production. Multiply at $5^{\circ}$ $47^{\circ} \mathrm{C}$ (great $37^{\circ} \mathrm{C}$ ), preferentially in $\mathrm{pH}$ higher than 4.0 and water activity 0,95. More than 2500 serotypes of Salmonella are known, classified by somatic and flagellar antigens according to Kauffman-White scheme (EL ALLAOUI et al., 2013; VON RUCKERT et al., 2009;
BERCHIERI JÚNIOR \& FREITAS NETO; WHO, 2000).

In all the outbreaks reported in European Union (EU) at 2015, 33.7\% occurred by bacteria and Salmonella was the most important etiological agent (21.8\% (EFSA, 2016). Some serotypes can infect poultry and almost all serovars are considered as potentially pathogenic to human beings and are associated to FD. However, ten serovars are responsible by around $85 \%$, and only three serovars contribute with more than $1 \%$ each one - S. Enteritidis, $S$. Typhimurium and $S$. Infantis.

Salmonella enterica serovar Enteritidis is the serotype more frequente associated to FD in european countries and it is responsible by $45.57 \%$ of more than 94 mil cases at 2015 (KANG et al., 2017; EFSA, 2016).

The infections caused by Salmonella spp. result in gastroenteritis, fever, abdominal pain, emesis, diarrhoea and headache. Commonly the infection is limited and the symptoms are observed during one to seven days, however, the symptoms are worse in susceptible individuals such as children, seniors or immunological compromised. Salmonella genus is one of the most important in fatal cases and the gravity is related to factors as serotype and number of microorganisms which were ingested (WHO, 2000).

They are pathogens with importance to food industries and to public health due their impact on morbidity and economical costs, and are considered important criteria for microbiological evaluation of food (VON RUCKERT et al., 2009). 
Silva et al., Revista Brasileira de Higiene e Sanidade Animal (v.11, n.3) p. 338 - 353, jul - set (2017)

Turkey meat contamination by Salmonella spp. is directly linked to poultry contamination in farms. This genus is reported in feather, sking, foot and gastrointestinal tract allowing contamination during processing (KNÖBL et al., 2000). The contamination sources are several and similar to poultry, beginning on transport and followed by steps in slaughterhouses such as scalding, feather removal, and mainly evisceration, resulting from rupture of intestines and contact with carcasses (PACHOLEWICZ et al., 2016; EFSA 2016; EL ALLAOUI et al., 2013; POPPE, 2000). Turkey evisceration is commonly automatized, however, the manual way is adopted when unstandardized groups are slaughter turning the risk higher (PACHOLEWICZ et al., 2016; CIBIN et al., 2014; HAFEZ, 2001).

Due the risk for public health, the prevention of the transmission of Salmonella spp. through food is a priority to Brazilian poultry production chain (OLIVEIRA \& SILVA, 2000). Thus, the "Program of Pathogens Reduction (PPR) - Microbiological Monitoring and Control of Salmonella spp. in poultry and turkey carcasses" were established by Brazilian Ministry of Agriculture, Livestock and Food Suply (MAPA) through Normative Instruction $\mathrm{n}^{\circ}$ 70. This program is focused on monitor the contamination levels of this microorganism through processing control, based on Good Manufacturing Practices (GMP) and Hazard Analysis and Critical Control Points (HACCP) (BRASIL, 2003). This program is considered as efficient because the prophylactic practices are adopted across the production chain, from farm to consumers. Some measures, such as to don't allow the slaughter of infected groups detected on farms together with negative groups, and the cleaning and disinfection when infected groups are slaughter, contributes to avoid the widespread of this pathogen in slaughterhouses (PALMEIRA et al., 2016; ANTUNES et al. 2016).

Salmonellosis through poultry meat consumption affects not only developing countries but also developed ones. Turkey meat was responsible by more than the double of salmonellosis cases compared to poultry meat at decade 80 even in developed countries such as USA and United Kingdom (UK) (EL ALLAOUI et al., 2013).

Synnott et al. (1998) reported an outbreak caused by $S$. Agona at 1996 at Stafford, England, involved pre-cooked turkey meat.

Studies using epidemiological data from outbreaks occurred in USA from 1998 to 2008 estimated that 20,000 hospitalizations occurred due FD in the country and $11 \%$ due salmonellosis. Turkey meat was responsible by $22 \%$ of hospitalizations (SCALLAN et al., 2011). Another study in Turkey, Salmonella spp. was isolated from $110(45.8 \%)$ from the set of 240 turkey meat samples (ISERI \& EROL, 2010).

The occurrence of Salmonella spp in turkey meat sold in USA during 2007 was evaluated. A set of 959 samples were evaluated (345 of raw meat and 614 ready to eat). From them, $4.1 \%$ and $1.1 \%$ were contaminated, respectively (KHAITSA et al., 2007). 
Silva et al., Revista Brasileira de Higiene e Sanidade Animal (v.11, n.3) p. 338 - 353, jul - set (2017)

Between 2006 and 2010, salmonellosis cases in EU reduced 40.6\% (EFSA, 2012). This reduction is probably linked to pathogens control programs. Antunes et al. (2016) and EFSA (2017) reported that the efficacy of these programs instituted in EU at 2007 reduced the occurrence in the last decade.

During this period, the prevalence of serovars in reported cases have been modified. The serovars $S$. Enteritidis (responsible by 45 $64 \%$ of the cases between 2007 and 2010), S. Typhimurium and $S$. Infantis are the most important in EU, followed by $S$. Virchow and $S$. Newport. However, at 2010, the emergent $S$. Typhimurium monophasic 1,4,[5],12:i:- got the 4st position, and since 2013, it is considered the third most frequent. Others important serovars were established such as $S$. Stanley, $S$. Derby e $S$. Bredeney (EFSA, 2016).

The reasons for the observed reduction are several but the effect of these programs were crucial to reduce the total number of salmonellosis cases (EFSA, 2016). The antimicrobial resistance can contribute to explain the dissemination of emerging strains, and this point will be discussed later in this review.

Outbreaks due turkey meat consumption occurred due ingestion of a uncommon serovar $S$. Stanley when more than 700 cases were reported at 10 different countries in EU during 2011-2012 (KINROSS, 2014). At 2015, Salmonella was most detected in poultry meat $(6.5 \%)$, followed by turkey meat $(4.6 \%)$ (EFSA, 2016). The serovars $S$. Stanley, $S$. Newport and $S$. Bredeney were the most commonly reported serovars (EFSA, 2016).
Salmonelossis is also considered as an important problem due antimicrobial resistance. The improper use of antimicrobial contributed to the emergence of resistant microorganisms (WHO, 2000). The improper use of antimicrobial in turkey production chain is worrying from a long time due its contribution to the dissemination of resistant strains (SINGER \& HOFACRE, 2006). The strains of emerging Salmonella, from turkey are more resistant than those from poultry (Nde \& Logue, 2008).

The emergence of Salmonella isolates resistanto to antimicrobials importante in human health, such as fluorquinolone, ciprofloxacine and cephalosporin, disseminated acroos turkey production during 1990 at USA and Canadá (EFSA, 2012).

Khaitsa et al. (2007) evaluated isolates obtained from turkey meat sold in USA and verified six serotypes - $S$. Hadar, $S$. Heidelberg, $S$. Typhimurium var. Copenhague, $S$. Newport, S. Saintpaul and S. Agona; which were evaluated to 15 antimicrobial used in human treatment. Resistance to tetracycline (76\%), sulfisoxazole (43\%), chloramphenicol (38\%) and ampicillin (38\%) was observed.

In a study performed by Iseri \& Erol (2010), Salmonella spp. was isolated from 110 from 240 samples of ground turkey meat. From 110 isolates, 54 (49\%) were resistant to antimicrobial. The highest resistance were observed to nalidixic acid (25.4\%), streptomycin $(17.2 \%)$ and tetracycline (15.4\%). Also, $9.9 \%$ of these isolates were multiple resistant to four or more antimicrobials. 
Silva et al., Revista Brasileira de Higiene e Sanidade Animal (v.11, n.3) p. 338 - 353, jul - set (2017)

Nwachukwu e Nnamani, (2013) isolated these microorganisms from frozen turkey meat sold in Nigeria. The isolates had high resistance to ampicillin and streptomycin.

There is a lack of information in literature about this topic in Brazil related to turkey meat, highlighting the need of studies in order to verify and elucidate the real situation of this meat in this country.

PALMEIRA et al. (2016) suggested that the adoption of sanitary programs in Brazil is efficient resulting in the low number of cases registered in this country as have been shown in EU, where there was a reduction trend of $30 \%$ in the number of cases through the last decade (ANTUNES et al., 2016; EFSA; 2016).

Besides the reasons for this reduction be unclear in several countries, a great proportion can be attributed to the sanitary programs focused on Salmonella control during turkey raising because the prevalence in turkey is considered as the main risk factor for meat contamination during processing (HUGAS \& BELOEIL; 2014).

It is known that surveillance programs and also recall practices have high costs and are neglected in the majority of developing countries (WAGENAAR et al., 2013). However, the lack of information in literature regarding the situation in Brazil linked to turkey meat impacts the monitoring and control of risks to consumers, and also the development of this production chain, because the real situation of the final products remains unknown.

\section{Campylobater spp.}

The diseases caused by the genus Campylobacter are worldwide distributed and considered one of the most important FD, constituting the second most frequent cause of bacterial diarrhoea at USA and EU. Poultry meat is considered the mainly food involved in outbreaks (EFSA, 2016; WAGENAAR et al., 2013; LAHUERTA et al., 2011). The cases commonly occur isolated and sporadically and sometimes are not identified in outbreaks (CDC, 2008). The costs due campylobacteriosis is estimated on U\$1.7 billion annually (WAGENAAR et al., 2013).

This microorganism is found in poultry's gastrointestinal micro flora, gram-negative bacilli, mobile, without spores production, curved stick ("," or " $\mathrm{S}$ "). The optimum $\mathrm{pH}$ is around $6.5-7.5$, temperature $42-45^{\circ} \mathrm{C}$. It is sensible to heating, salts, low $\mathrm{pH}$ and humidity (WHO, 2000; EFSA, 2016). The symptoms can persist up to 10 days and they are characterized by fever, abdominal pain, emesis, diarrhea (sometimes containing blood or mucus). Few cases $(2 \%)$ can result in meningitis, UHS and Guillain-Barré syndrome (WHO, 2000).

There are approximately 16 species associated to campylobacteriosis but the most detected are C. jejuni, C. coli, and C. upsaliensis. The most prevalent specie is $C$. jejuni which is responsible by $15 \%$ of the cases that resulted in hospitalization linked to FD and $6 \%$ of the death (ADDIS \& SISAY, 2015). Afterwards, Campylobacter coli is the second most important specie. Others species such as $C$. lari, $C$. upsaliensis, C. fetus had already been reported but with a lower significance worldwide 
Silva et al., Revista Brasileira de Higiene e Sanidade Animal (v.11, n.3) p. 338 - 353, jul - set (2017)

(WAGENAAR et al., 2013). Thus, this review focused on the species $C$. jejuni e $C$. coli.

The principal risk for campylobacteriosis occurrence in human beings is associated with consumption of poultry's meat products (ALTER \& SHERER, 2006). Turkey and other animals are reservoirs for this microorganism by asymptomatic infection in gastrointestinal tract. The faecal contamination sources of turkey carcasses are similar to those described for poultry during processing, mainly scalding and evisceration (PACHOLEWICZ et al., 2016; CIBIN et al., 2014; BELLUCO et al., 2016; ADDIS \& SISAY, 2015; EL ALLAOUI et al., 2013; ZHAO et al., 2001).

Studies shown that Campylobacter spp. infections in poultry are commonly correlated with E. coli and Salmonella spp., mainly animals groups which are not standardized (PACHOLEWICZ et al., 2016; CIBIN et al., 2014).

Turkey evisceration lines in processing industries are automatized in the major of countries, however this step can be performed manually in groups not standardized, mainly turkey males and females (20 and $10 \mathrm{~kg}$, respectively). On this situation, evisceration increases the risk for faecal contamination through intestinal rupture and contact with carcasses (HAFEZ et al., 2001).

The risks for consumers are directly proportional to the contamination level of food. The multiplication of these microorganisms does not occur outside intestines, thus, the population is limited to initial population through processing. The most effective practice to control this disease is to monitor processing and to avoid consumption of food high-contaminated (WAGENAAR et al., 2013b).

At Denmark, the number of notified and confirmed cases of campylobacteriosis increased through 1992 to 1999, with 78 cases per 100,000 inhabitants infected with this disease (NIELSEN et al., 2000). The same trend was observed in England and Wales (DESAI et al., 2001).

C. jejuni was responsible by $40.5 \%$ of the cases in Japan from 1996 to 2000 (OBANA et al., 2002). In Czech Republic, 20,000 cases were registered at 2000 (STEINHAUSEROVÁ et al., 2002).

ZHAO et al. (2001) evaluated the occurrence of Campylobacter spp. in a set of 825 samples of commercial meat (172 turkey meat) and $25(14.5 \%)$ were contaminated. Poultry meat was the most frequent contaminated with Campylobacter spp. (70.7\%), followed by turkey meat (14.5\%). In New Zeland, the number of notifications increase from 2000 to 2007 (WAGENAAR et a., 2013).

The incidence of infections caused by Campylobacter spp. was higher than Salmonella at EU during 2004 for the first time (CDC, 2008). The number of confirmed cases of campylobacteriosis during 2015 was around 230,000 in EU, with $27 \%$ hospitalizations, with an increasing trend since 2008 (EFSA, 2016).

Besides the fact that this bacteria is commonly studied in developed countries, actually, there is not a surveillance system for Campylobacter at EU (EFSA, 2016), and the importance of this genus as a FD remains unknown at Brazil. Campylobacteriosis is not 
Silva et al., Revista Brasileira de Higiene e Sanidade Animal (v.11, n.3) p. 338 - 353, jul - set (2017)

well studied in the country, probably due the biological characteristics of this microorganism, requiring specific conditions for isolation and identification. Thus, campylobacteriosis can be a neglected disease and a national concern for public health (ESTEVES et al., 2011).

\section{Escherichia coli}

Escherichia coli belong to

Enterobactereriae family, gram-negative bacilli and facultative anaerobe. Commonly mesophilic multiply at $7-50^{\circ} \mathrm{C}$ (optimum $37^{\circ} \mathrm{C}$ ), Aw 0.95 and $\mathrm{pH}$ 4.4-4.8 (WHO, 2000). Enterobacteriaceae are considered as indicators of food quality, including E. coli, mainly due faecal contamination (VALERO et al., 2016). The strains are described: enteropathogenic $E$. coli (EPEC); enterotoxigenic E. coli (ETEC), producer of thermo stable and thermo labile toxins; enteroinvasice E. coli (EIEC); and enterohemorrhagic E. coli (EHEC) or verotoxigenic $E$. coli (VTEC), also known as shiga toxin-producing E. coli (STEC) from which E. coli $\mathrm{O} 157$ is the most known (WHO, 2000).

E. coli O157: $\mathrm{H7}$ is one of the 60 serotypes verotoxin producers and it is known as the main serotype linked to FD. Its consumption cause several symptoms, including diarrhoea, haemorrhagic colitis and haemolytic-uremic syndrome (ADDIS \& SISAY, 2015). It is the serotype most studied due its high pathogenicity, however, other serotypes also are involved in FD outbreaks (VALERO et al., 2016).

The occurrence of these microorganisms in outbreaks is associated with improper sanitation, bad hygienic practices and cross- contamination with surfaces and equipment in processing environment, because the majority of strains habit the intestines from warm blooded animals (WHO, 2000). It is a microorganism with great importance for public health and considered as parameter in several regulations worldwide.

The Service of Safety and Inspection of Food from USA created at 1996 the "Pathogen Reduction (PR) - HACCP System's Final Rule", which established the maximum enumeration of E. coli of $10^{3} \mathrm{CFU} / \mathrm{mL}$ using a sampling scheme of 1/3000 turkey carcasses (BELLUCO et al., 2016). In Brazil, the current legislation (RDC $n^{\circ}$ 12/2001 - ANVISA), establishes the maximum count of $10^{4} \mathrm{CFU} / \mathrm{g}$ for thermotolerant coliforms, which contain a high proportion of $E$. coli (BRAZIL, 2001).

Data regarding the importance of turkey meat in STEC infections showed that there was 6,025 cases, including 5,901 confirmed, reported in EU at 2015 (EFSA, 2016). In Brazil, unpublished data reported E. coli on $6.14 \%$ of turkey meat samples obtained in several supermarkets in the state of São Paulo (SILVA, et al., 2017, submmited).

Another factor involving E. coli is the resistance to antimicrobials. E. coli is the main cause of economic losses linked to diseases in poultry farms worldwide. Consequently, it is the principal microorganism avoided through use of antimicrobial (BARNES et al., 2003).

The plasmided linked to multiple resistance to drugs, which codifies $\beta$-lactamase (bla), that was disseminated on E. coli and other Enterobacteriaceae, was exported from Canadá 
Silva et al., Revista Brasileira de Higiene e Sanidade Animal (v.11, n.3) p. 338 - 353, jul - set (2017)

at 1990 to UK through turkeys (EFSA, 2012). Since that, the plasmids vary on size and compatibility with other plasmids, and have a great capacity of transfer across species. Its dissemination is an increasing concern for public health (SEIFFERT et al., 2017; CARATTOLI; 2013).

\section{Listeria monocytogenes}

L. monocytogenes is a gram-positive microorganism, facultative anaerobe (WHO, 2000).

This bacterium can multiply inside host's cells and is one of the most pathogenic microorganisms involved in FD outbreaks with a lethality of 20-30\% (ADDIS \& SISAY, 2015). On around $19 \%$ of the death occurred in Europe at 2015 were attributed to poultry and the majority of death linked with poultry were caused by Listeria or Salmonella spp. (EFSA, 2016). The consequences are worse for children, seniors and immunocompromised (BEHRAVESH, 2012). Besides its virulence, listeriosis incidence has decreasing in the last three decades, with an occurrence of only 15 outbreaks registered from 1980 to 2000 in EU. Turkey meat was linked only to two of them (GOTTLIEB et al., 2006; OLSEN et al, 2005). Other two outbreaks were registered by USDA at 2000 and 2001 involving turkey meat (FRYE et al., 2002; CDC, 2002).

At EU, L. monocytogenes was detected in turkey meat products in two recent investigations; one during processing in Spain, and the other in markets at Hungary. The percentage of detection was $1.7 \%$ on markets and $1.4 \%$ on processing (EFSA, 2016).
Thus, turkey meat appears to don't have a significant importance for listeriosis cases in developed countries. However, at Brazil and other developing countries, listeriosis is not well studied and its occurrence can be under estimated.

\section{Staphylococcus spp.}

The Staphylococcus genus belongs to the family Micrococcaceae and they are grampositive, aerobes or facultative anaerobes, multiply at $7-48^{\circ} \mathrm{C}$ (optimum $37^{\circ} \mathrm{C}$ ) and produce enterotoxins from 10 to $46^{\circ} \mathrm{C}, \mathrm{pH} 4.0-9.3$ (optimum 7.0), aW 0.8 and resist to salt concentrations on around 10-20\% (WHO, 2000; BERGDOLL \& BENNETT, 1989). The species with importance for food safety are $S$. hyicus, $S$. chromogenes, $S$. intermedius and $S$. aureus. The last one is the most importance and it is associated with $98 \%$ of outbreaks of this genus (SANTANA et al., 2010; SU\&WONG, 1997). This microorganism has a great importance due its potential to result in intoxications (ZECCONI \& HAHN, 2001; DINGES et al., 2000).

The presence of other microorganisms is a limitation factor to Staphylococcus spp. multiplication in food (LOIR et al., 2003). However, the intoxications are caused through ingestion of pre-formed thermo stable on food (BREWER, 1991). Concentrations ranging from $100 \mathrm{ng}$ to $1 \mu \mathrm{g}$ are enough to cause intoxication in susceptible individual, which is found on populations on about $10^{5}$ CFU/g (SANTANA, 2010).

The incubation and severity of symptoms are dependent of the quantity of enterotoxin ingested and individual susceptibility (CUNHA 
Silva et al., Revista Brasileira de Higiene e Sanidade Animal (v.11, n.3) p. 338 - 353, jul - set (2017)

NETO et al., 2002). The mainly symptoms are emesis and abdominal pain, beginning from 2-24 hours after the ingestion of contaminated food. However, the intoxication is rarely lethal (WHO, 2000).

This bacterium is found on human's skin, mouth and nose, allowing food contamination through improper practices (MURRAY et al., 2000). A percentage of $50 \%$ of the health human beings are carriers of $S$. aureus (VANZO \& AZEVEDO, 2003; BERGDOLL \& BENNETT, 1989).

Its presence in meat indicates improper hygienic conditions, commonly after processing, due food handlers with low technical level or not trained for this function. Also, the contamination occurs due improper hygiene of equipment (JAVADI et al. 2014; ASLAM et al., 2004; CUNHA NETO et al., 2002). Some studies had shown that the presence of this microorganism on equipment and surfaces in meat industries due deposition of organic material which affects sanitation (KUSUMANINGRUM et al., 200; KARMI, 2013). The contamination on poultry meat can be significant on stainless surfaces and have great importance during processing or packaging (SON et al., 2016; MALHEIROS et al., 2010).

The presence of methicillin-resistant $S$. aureus (MRSA) on food sold on supermarkets has getting a high importance recently (ABDALRAHMAN et al., 2015). Some studies had isolated MRSA in turkey meat with a prevalence higher than poultry meat in USA (ABDALRAHMAN et al., 2015; HANSON et al., 2011; BHARGAVA et al., 2011) and Europe (FESSLER et al., 2011; DE BOER et al., 2009).

Unpublished data showed that $12.7 \%$ of turkey meat was contaminated with positivecoagulase Staphylococcus in the state of São Paulo, Brazil (SILVA, et al., 2017, submmited). To prevent this intoxication, it is important the health of food handlers, refrigeration during storage in order to avoid bacterial growth and toxins production, not allowing outbreaks (WHO, 2000).

\section{Clostridium botulinum}

Clostridium botulinum is spore-producer anaerobe bacilli, gram-positive, widespread in the enviroment. They produce seven distinct toxins (A to $\mathrm{G}$ ), but only $\mathrm{A}, \mathrm{B}, \mathrm{E}$ and $\mathrm{F}$ are linked to FD. The proteolytic strains producers of $\mathrm{A}, \mathrm{B}$ and $\mathrm{F}$ toxins are mesophilic and multiply from 10 to $50^{\circ} \mathrm{C}$. Non-proteolytic strains are psychtrophic and multiply on around $3^{\circ} \mathrm{C}(\mathrm{WHO}$, 2000).

The spores are resistant to temperatures of cooking and survive to dry process and freezing. The toxins are destructed by proper thermal treatment (boiling during 15 minutes). They are potentially lethal on low quantities binding the neuromuscular junctions, blocking nervous transmission resulting on flaccid paralysis (ADDIS \& SISAY, 2015; WHO, 2000).

Besides it is the FD more associated to hospitalizations $(71.7 \%)$, the notification of outbreaks is rare in poultry and turkey meat. Recently, it is becoming more relevant on fish at developed countries compared to poultry meat, with a decreasing trend across the time (EFSA, 
Silva et al., Revista Brasileira de Higiene e Sanidade Animal (v.11, n.3) p. 338 - 353, jul - set (2017)

2016). However, the detection of C. botulinum in turkey during raising in Europe (Popp et al., 2012; Gad et al., 2011) and Brazil (Lobato, 2009) is reported.

\section{Clostridium perfringens}

Clostridium perfringens is a sporeproducer bacilli, gram-positive. The FD is caused mainly by microorganisms that produce enterotoxin type A than other types (B to $G$ ). Multiply from $12^{\circ} \mathrm{C}$ to $50^{\circ} \mathrm{C}$ (optimum $43-47^{\circ} \mathrm{C}$ ), pH 6-7, aW < 0.95 (WHO, 2000).

The disease is characterized by acute abdominal pain, diarrhoea, emesis, and the symptoms persist up to 24 hours. The mortality is low and restricted to seniors (ADDIS \& SISAY, 2015).

Besides the detection of C. perfringens on turkey meat (Erol et al., 2008), the registers and notifications of FD have been decreasing. A reduction of $22 \%$ was observed on the notifications at EU from 2014 to 2015. The main risks are associated with the consumption of beef and pork, and turkey meat is not relevant actually (EFSA, 2016).

\section{Final considerations}

Considering the risk factors and the implication on foodborne outbreaks linked to turkey meat, a higher risk for public health was attributed to Salmonella spp., Escherichia coli and Staphylococcus spp., mainly through transmission of resistant microorganisms, and also Campylobacter sp., because it is pathogenic microorganism commonly associated with the mentioned microorganisms, however, neglected on developing countries. Besides the highvirulence of Listeria monocytogenes, its occurrence in turkey meat have been decreasing across the time and it is not considered a great risk for this meat. The same was observed for Clostridium botulinum and Clostridium perfringens. There is a need of a higher incentive for researches aiming to verify the conditions of the processing of turkey meat, and also to monitor this meat sold in the country.

\section{Acknowledgement}

We would like to thank the São Paulo Research Foundation due scholar grant (Grant 12/11057-0).

\section{References}

1.ABDALRAHMAN, L. S.; STANLEY, A.; WELLS, H.; FAKHR, M. K. Isolation, virulence, and antimicrobial resistance of methicillin-resistant Staphylococcus aureus (MRSA) and methicillin sensitive Staphylococcus aureus (MSSA) strains from Oklahoma retail poultry meats. International journal of environmental research and public health, v.12, n.6, p.6148-6161, 2015.

2. ABPA. Relatório anual 2016 - Associação Brasileira de Proteína Animal, 2016. 136p. Disponível em: < http://abpabr.com.br/setores/avicultura/publicacoes/relatoriosanuais $>$.

3. ADDIS M.; SISAY, D. A Review on Major Food Borne Bacterial Illnesses. Journal of Tropical Disease. V.3, p.176, 2015.

4. ALTER, T.; SCHERER, K. Stress response of Campylobacter spp. and its role in food processing. Journal of Veterinary Medicine, Series B, v.53, n.8, p.351-357, 2006.

5. ANTUNES, P.; MOURÃO, J.; CAMPOS, J.; PEIXE, L. Salmonellosis: the role of poultry meat. Clinical Microbiology and Infection, v.22, n.2, p.110-121, 2016.

6. AMERICAN PUBLIC HEALTH ASSOCIATION (APHA). Committee on microbiological metods for foods. Compendium of methods for the microbiological examination of foods. 4 ed. Washington: APHA, 2001. 676p. 
7. APHA American Public Health Association. 2000. Control of Communicable Diseases Manual. J. Chin, Editor. Washington, DC. 624 pp.

8. ASLAM, M.; GREER, G. G.; NATTRESS, F. M.; GILL, C. O.; McMULLEN, L. M. Genotypic analysis of Escherichia coli recovered from product and equipament at a beef packing plant. Journal of Applied Microbiology, v.97, p.78-86, 2004.

9. BARNES, H. J.; VALLIANCOURT, J.P.; W. B. GROSS. Colibacillosis. In: Diseases of poultry, 11th ed. Y. M. Saif, ed. Iowa State Press, Ames, IA. pp. 631-652. 2003.

10. BELLUCO, S.; BARCO, L.; ROCCATO, A.; RICCI, A. Escherichia coli and Enterobacteriaceae counts on poultry carcasses along the slaughterline: A systematic review and meta-analysis. Food Control, v.60, p.269-280, 2016.

11. BEHRAVESH, C.B.; WILLIAMS, I.T.; TAUXE, R.V. Emerging foodborne pathogens and problems: expanding prevention efforts before slaughter or harvest. In: Institute of Medicine (US). Improving Food Safety Through a One Health Approach: Workshop Summary. Washington (DC): National Academies Press (US); 2012.

12. BERCHIERI JÚNIOR, A.; FREITAS NETO, O. C. Salmoneloses aviárias. In: BERCHIERI JÚNIOR, A.; SILVA, E. N.; DI FÁBIO, J.; SESTI, L.; ZUANAZE, M. A. F. Doenças das aves. 2. ed. Campinas: FACTA, seção. 4, p.435-454, 2009.

13. BERGDOL, M. S, BENNETT, R.W. Staphylococcal Enterotoxins. In: Compendium of Methods for the Microbiological Examination of Foods. Ch. 34. 2a Ed. American Public Health Association; Washington, p.428-457, 1989.

14. BHARGAVA, K.; WANG, X.; DONABEDIAN, S.; ZERVOS, M.; DA ROCHA, L.; ZHANG, Y. Methicillin-resistant Staphylococcus aureus in retail meat, Detroit, Michigan, USA. Emerging infectious diseases, v.17, n.6, p.1135, 2011.

15. BRASIL. Ministério da Agricultura. Instrução normativa $\mathrm{n}^{\circ} 70$, de 06 de outubro de 2003. p. 9, 10 de outubro de 2003. Seção 1. Programa de redução de patógenos monitoramento microbiológico e controle de Salmonella spp. em carcaças de frangos e perus. Brasília: Ministério da Agricultura, Pecuária e Abastecimento - MAPA /Secretaria de Defesa Agropecuária; 2003.

16. BRASIL, Ministério da Agricultura Pecuária e Abastecimento. Instrução Normativa $\mathrm{n}^{\circ} 70$, de 06 de outubro de 2003. Programa de Redução de Patógenos - Monitoramento Microbiológico e Controle de Salmonella spp. em Carcaças de Frangos e Perus, 2003. Diário Oficial [da] República Federativa do Brasil, Brasília, DF 10 de Outubro de 2003, seção 1, p. 9.

17. BRASIL. Ministério da Saúde. Agência Nacional de Vigilância Sanitária. Resolução RDC no 12 de 02 de janeiro de 2001. Dispõe sobre o regulamento técnico sobre padrões microbiológicos para alimentos. Diário Oficial [da] República Federativa do Brasil, Brasília, DF, 10 de jan. 2001.

18. BRASIL. Ministério da saúde. Secretaria de Vigilância em Saúde. Manual integrado de vigilância, prevenção e controle de doenças transmitidas por alimentos. 2010. 160p.

19. BREWER, M. S. Food storage, food spoilage, and foodborne illness. University of Illinois at Urbana-Champaign, College of Agriculture, Cooperative Extension Service. 1991.

20. CARATTOLI A. Plasmids and the spread of resistance. International Journal of Medical Microbiology. v.303, p.298-304. 2013.

21. CAVALli, S.B. Segurança alimentar: a abordagem dos alimentos transgênicos. Revista Nutrição, Campinas, v.14, p.41-46, 2001.

22. CENTERS FOR DISEASE CONTROL AND PREVENTION (CDC). Preliminary FoodNet data on the incidence of infection with pathogens transmitted commonly through food -10 states, 2006. Campylobacter. MMWR. Morbidity and mortality weekly report, v. 56, n. 14, p. 336, 2007.

23. CIBIN, V.; MANCIN, M.; PEDERSEN, K.; BARRUCCI, F.; BELLUCO, S.; ROCCATO, A.; COCOLA F.; FERRARINI S.; SANDRI A., LAU BAGGESEN D.; RICCI A. Usefulness of Escherichia coli and Enterobacteriaceae as Process Hygiene Criteria in poultry: experimental study. EFSA Supporting Publications, v.11. n.8, 2014.

24. COSTA, F. Caracterização do processo de rigor mortis e da maciez do músculo Gastrocnemius e Pectorallis e efeito da radiação gama na vida comercial da carne de peru (Meleagris gallopavo). 2006. 137f. Tese (Doutorado) - Universidade Federal Fluminense, Niterói, 2006.

25. CUNHA NETO, A., SILVA, C. G. M., STAMFORD, T. L. M. Staphylococcus enterotoxigênicos em alimentos in natura $\mathrm{e}$ processados no estado de Pernambuco, Brasil. 
Ciência e Tecnologia dos Alimentos, Campinas, v.22, n.3, p.263-271, 2002.

26. DE BOER, E.; ZWARTKRUIS-NAHUIS, J. T. M.; WIT, B.; HUIJSDENS, X. W.; DE NEELING, A. J.; BOSCH, T.; HEUVELINK, A. E. Prevalence of methicillin-resistant Staphylococcus aureus in meat. International journal of food microbiology, v.134, n.1, p.52-56, 2009.

27. DESAI, M.; LOGAN, J. M. J.; FROST, J. A.; STANLEY, J. Genome sequence-based fluorescent length polymorphism of Campylobacter jejuni, its relationship to serotyping, and its implications for epidemiological analysis. Journal of Clinical Microbiology, Washington, v.39, n.11, p.3823-3829, 2001.

28. DINGES, M.M.; ORWIN, P.M.; SCHLIEVERT, P.M. Exotoxins of Staphylococcus aureus. Clinical Microbiology Review, v.13, p.16-34, 2000.

29. EFSA (European Food Safety Authority), Scientific Opinion of the Panel on Biological Hazards on a request from the European Food Safety Authority on foodborne antimicrobial resistance as a biological hazard. The EFSA Journal. 2008. 765p.

30. EFSA Panel on Biological Hazards (BIOHAZ). Scientific Opinion on an estimation of the public health impact of setting a new target for the reduction of Salmonella in turkeys. EFSA Journal. v.10, n.4. 2012. $2616 \mathrm{p}$.

31. EFSA Panel on Biological Hazards (BIOHAZ). Scientific Opinion on monitoring and assessment of the public health risk of "Salmonella Typhimuriumlike" strains. EFSA Journal, v.8, n.10, 2010. 1826 p.

32. EL ALLAOUI, A.; FILALI, F. R.; DEROUICH, A.; KARRAOUA, B.; AMEUR, N.; BOUCHRIF, B. Prevalence of Salmonella Serovars Isolated from Turkey Carcasses and Giblets in Meknès-Morocco. Journal of World's Poultry Research, v.3, p.93-98, 2013.

33. EUROPEAN FOOD SAFETY AUTHORITY (EFSA) Scientific Opinion on an estimation of the public health impact of setting a new target for the reduction of Salmonella in turkeys. EFSA Journal, v.10, n.4, 2012.

34. EUROPEAN FOOD SAFETY AUTHORITY (EFSA). The European Union summary report on tren ds and sourcesof zoonoses, zoonotic agents and food-borne outbreaksin 2015. EFSA Journal, v.14, n. 12, p.4634, 2016.

35. EROL, I.; GONCUOGLU, M.; AYAZ, N. D.; BILIR ORMANCI, F. S.; HILDEBRANDT, G. Molecular typing of Clostridium perfringens isolated from turkey meat by multiplex PCR. Letters in applied microbiology, v.47, n.1, p.31-34, 2008.

36. ESTEVES, W. T. C.; FERREIRA, A. P.; \& SICILIANO, S. Potencial impacto na Saúde Pública por Campylobacter spp. Estudo de caso: curso inferior do rio São João, RJ, Brasil. Cadernos Saúde Coletiva, v.19, n.1, p.74-81, 2011.

37. FEßLER, A. T.; KADLEC, K.; HASSEL, M.; HAUSCHILD, T.; EIDAM, C.; EHRICHT, R.; MONECKE, S.; SCHWARZ, S. Characterization of methicillin-resistant Staphylococcus aureus isolates from food and food products of poultry origin in Germany. Applied and environmental microbiology, v.77, n.20, p.7151-7157, 2011.

38. FRYE, D. M.; ZWEIG, R.; STURGEON, J.; TORMEY, M.; LECAVALIER, M.; LEE, I.; MASCOLA, L. An outbreak of febrile gastroenteritis associated with delicatessen meat contaminated with Listeria monocytogenes. Clinical infectious diseases, 35(8), 943-949. 2002.

39. GAD, W.; R. HAUCK, M. KRU“GER, AND H. M. HAFEZ. Prevalence of Clostridium perfringens in commercial turkey and layer flocks. Arch. Geflkd. 75(2):74-79. 2011.

40. GOTTLIEB, S.L, NEWBERN, E.C, GRIFFIN, P.M, GRAVES, L.M, HOEKSTRA, R.M, BAKER, N.L, Multistate outbreak of listeriosis linked to turkey deli meat and subsequent changes in US regulatory policy. Clinical Infectious Diseases. V.42, p.29-36. 2006.

41. HANSON, B.M.; DRESSLER, A.E.; HARPER, A.L.; SCHEIBEL, R.P.; WARDYN, S.E.; ROBERTS, L.K.; SMITH, T.C. Prevalence of Staphylococcus aureus and methicillin-resistant Staphylococcus aureus (MRSA) on retail meat in Iowa. Journal of Infection and Public Health, 4(4), 169-174. 2011.

42. HAVELAAR, AH,; KIRK, M.D,; TORGERSON, P.R,; GIBB, H.J,; HALD, T,; LAKE, R.J,; NICOLAS, PRAET, DAVID, C.; BELLINGER, NILANTHI, R. DE SILVA, NEYLA GARGOURI, NIKO SPEYBROECK, AMY CAWTHORNE, COLIN MATHERS, CLAUDIA STEIN, 
FREDERICK, J. ANGULO, BRECHT DEVLEESSCHAUWER. World Health Organization Global Estimates and Regional Comparisons of the Burden of Foodborne Disease in 2010. PLoS Med 12(12). 2015. e1001923.

43. HUGAS, M.; BELOEIL, P.A. Controlling Salmonella along the food chain in the European Union - Progress overthe last ten years. Eurosurveillance, 19, 2-5. 2014.

44. ISERI, O.; EROL, I. Incidence and antibiotic resistance of Salmonella spp. in ground turkey meat. British Poultry Science, v. 51, p. 60-66. 2010.

45. JAVADI, A.; $S$. RAFEI; F. SHAHIAN; H.H. GHAZI. Isolation of coagulase-positive Staphylococcus aureus from meat and intestine of native ducks of Tabriz area. Journal Food Hygiene, 3: 55-62. 2014.

46. JOUKI, M.; TABATABAEI, F.; KHAZAEI, N.; MOTAMEDI SEDEH, F. Effects of Storage Time on Quality Characteristics of Frozen Turkey Meat. International Journal of Animal and Veterinary Advances. v. 4, n.1. p. 63-67. 2012.

47. KÄFERSTEIN, F.K.; MONTARJEMI, Y. Foodborne Disease Control: A Transnational Challenge. Disponível em: $<$ http://wwwnc.cdc.gov/eid/content/3/4/pdfs/v3n4.pdf $>$.

48. KANG, M.S.; JAE-YOUNG, O.H.; YONGKUK, k.; DEOG-YONG, L.; OK-MI, J.; BYUNGKOOK, C.; SO-YOUN, Y.; BYUNG-WOO, J.; HYE-JIN, L.; HEE-SOO, L. Public health significance of major genotypes of Salmonella enterica serovar Enteritidis present in both human and chicken isolates in Korea, Research in Veterinary Science, v. 112, p.125-131, 2017.

49. KARMI, M. Prevalence of methicillin-resistant Staphylococcus aureus in poultry meat in Qena, Egypt. Veterinary World, 6(10), 711-715. 2013.

50. KHAITSA M.L.; KEGODE R.B.; DOETKOTT D.K. Occurrence of antimicrobial-resistant Salmonella species in raw and ready to eat turkey meat products from retail outlets in the midwestern United States. Foodborne Pathogens and Disease, v.4, p. 517-525. 2007.

51. KINROSS P, VAN ALPHEN L, MARTINEZ URTAZA J, STRUELENS M, TAKKINEN J, COULOMBIER D, et al. Multidisciplinary investigation of a multicountry outbreak of Salmonella Stanley infections associated with turkey meat in the European Union, August 2011 to January 2013. Euro Surveill. 2014;19(19):p.20801, 2013.

52. KNÖBL, T.; FERREIRA, A.J.P.; FÁBREGA, V.L.A.; M.T.S.; ALCÂNTARA, M.T.S.; AYALA, J.L. Utilização de dióxido de cloro no controle de Salmonella sp em abatedouro de aves. Revista Brasileira de Ciência Avícola, v. 2, p. 92. 2000.

53. KUSUMANINGRUM, H. D.; RIBOLDI, G.; HAZELEGER, W. C.; BEUMER, R. R. Survival of foodborne pathogens on stainless steel surfaces and cross contamination to foods. International Journal of Food Microbiology, 85, 227-236. 2003.

54. LAHUERTA A.; WESTRELL T.; TAKKINEN J.; BOELAERT F.; RIZZI V.; HELWIGH B.; BORCK B.; KORSGAARD H.; AMMON A. \& MAKELA P. (2011). - Zoonoses in the European Union: origin, distribution and dynamics - the EFSA-ECDC summary report 2009. Euro Surveill, v.16, n.13, pii 19832.

55. LOIR, Y. LE; BARON, F.; GAUTIR, M. Staphylococcus aureus and food poisoning. Genetic Molecular Research, v.2, n.1, p.63-76, 2003.

56. MALHEIROS, P. S.; DOS PASSOS, C. T.; CASARIN, L. S.; SERRAGLIO, L.; TONDO, E. C. Evaluation of growth and transfer of Staphylococcus aureus from poultry meat to surfaces of stainless steel and polyethylene and their disinfection. Food Control, v.21, n.3, p.298-301, 2010.

57. MURRAY, P. R.; ROSENTHAL, K. S.; KOBAYASHI G. S.; PHALLEIC M. A. Microbiologia médica. 3a ed. Rio de Janeiro: Guanabara Koogan; 2000. 151 p.

58. NDE, C.W, LOGUE, C.M. Characterization of antimicrobial susceptibility and virulence genes of Salmonella serovars collected at a commercial turkey processing plant. Journal of Applied Microbiology, 104, 215-223, 2008.

59. NIELSEN, E.M.; ENGBERG, J.; FUSSING, V.; PETERSEN, L.; BROGREN, C.H.; ON, S.L. Evaluation of phenotypic and genotypic methods for subtyping Campylobacter jejuni isolates from humans, poultry, and cattle. Journal of Clinical Microbiology, Washington, v. 38 , n. 10, p. 38003810, 2000.

60. NWACHUKWU E. E NNAMANI O. H. Internetional Evaluation of turkey meat for bacteria and indicator microorganisms of public health importance. Journal of Current Microbiology and Applied Sciences. v.2 n.10. p. 224-229. 2013. 
611. OBANA, M.; SAGARA, H.; AOKI, T.; KIM, R.; TAKIZAWA, Y.; TSUNODA, T.; IRIMAJIRI, S.; YAMASHITA, K. The current status of infectious enteritis in Japan: reports of the "Research Group for Infectious Enteric Diseases, Japan" in the last 5 years (1996-2000). Ansenshogaku Zasshi, v. 76, n. 5, p. $355,2002$.

62. OLIVEIRA, D.D.; SILVA E.M. Salmonela em ovos comerciais: ocorrência, condições de armazenamento e desinfecção da casca. Arquivo Brasileiro de Medicina Veterinária e Zootecnia; v.52, n.6. p. 655-661. 2000.

63. OLSEN, S.J.; PATRICK, M.; HUNTER S.B.; REDDY, V.; KORNSTEIN, L.; MACKENZIE, W.R.; Multistate outbreak of Listeria monocytogenes infection linked to delicatessen turkey meat. Clinical Infectious Diseases. v.40, n.7, p.962-967, 2005.

64. PACHOLEWICZ, E.; SWART, A.; WAGENAAR, J. A.; LIPMAN, L.J.; HAVELAAR, A.H. Explanatory variables associated with Campylobacter and Escherichia coli concentrations on broiler chicken carcasses during processing in two slaughterhouses. Journal of food protection, v.79, n.12, p. 2038-2047, 2016.

65. PAINTER, J.A.; HOEKSTRA, R.M.; AYERS T.; TAUXE R.V.; BRADEN, C.R.; ANGULO, F.J.; GRIFFIN, P.M. Attribution of Foodborne Illnesses, Hospitalizations, and Deaths to Food Commodities by using Outbreak Data, United States, 1998-2008. Emerging Infectious Diseases. v. 19, n.3, 2013.

66. PALMEIRA, A.; SANTOS, L. R. D.; BORSOI, A.; RODRIGUES, L. B.; CALASANS, M.; NASCIMENTO, V. P. D. Serovars and antimicrobial resistance of Salmonella spp. isolated from turkey and broiler carcasses in southern Brazil between 2004 and 2006. Revista do Instituto de Medicina Tropical de São Paulo, v.58, 2016.

67. POPPE, C. Salmonella infections in the domestic fowl. In: Salmonella in domestic animals. Eds Wray $\mathrm{S}$ and Wray A. CABI Publishing, UK, p.107-132, 2000.

68. POPP, C.; HAUCK, R.; GAD, W.; HAFEZ, H.M. Type $\mathrm{C}$ botulism in a commercial turkey farm: a case report. Avian diseases, v.56, n.4, p.760-763, 2012.

69. REZENDE, C.S.M.; MESQUITA, A.J. de; ANDRADE, M.A.; LINHARES, G.F.C.; MESQUITA, A.Q.; MINAFRA, C.S. Sorotipos de Salmonella isolados de carcaças de frangos de corte abatidos no estado de Goiás, e perfil de resistência a antimicrobianos. Revista Portuguesa de Ciências Veterinárias, v.100, n.555- 556, p. 199-203, 2005.

70. ANTANA, E.H.W.; BELOTI, V.; ARAGONALEGRO, L.C.; MENDONÇA, M.B.O.C. Estafilococos em alimentos. Arquivo do Instituto Biológico. v.77, n.3, p.545-554, 2010.

71. SCALLAN, E.; HOEKSTRA R.M.; ANGULO, F.J.; TAUXE, R.V.; WIDDOWSON, M.A.; ROY, S.L.; JONES, J.L.; GRIFFIN, P.M. Foodborne illness acquired in the United States-Major pathogens. Emerging Infectious Diseases, v.17, p.7-15, 2011.

72. SEIFFERT, S.N.; CARATTOLI, A.; SCHWENDENER, S.; COLLAUD, A.; ENDIMIANI, A.; PERRETEN, V. Plasmids Carrying bla ${ }_{\mathrm{CMY}-2 / 4}$ in Escherichia coli from Poultry, Poultry Meat, and Humans Belong to a Novel IncK Subgroup Designated IncK2. Frontiers in Microbiology, v.8, 2017.

73. SILVA, H.O.; ROSSI, G.A.M.; AGUILAR, C.E.G.; VIDAL, A.M.C, ROSSI JUNIOR, O.D. Microbiological quality of frozen seasoned turkey meat. Ciência Rural, No prelo, 2017.

74. SINGER, R.S., HOFACRE, C.L. Potential Impacts of Antibiotic Use in Poultry Production. Avian Diseases. v.50, n.2, p.161-172, 2006.

75. SON H.; PARKA S.; LARRY ,R. BEUCHATB, HOIKYUNG KIMC, JEE-HOON RYU. Inhibition of Staphylococcus aureus by antimicrobial biofilms formed by competitive exclusion microorganisms on stainless steel. International Journal of Food Microbiology, v. 238, n.5, p. 165-171, 2016.

76. STEINHAUSEROVÁ, I.; CESKOVA, J.; NEBOLA, M. PCR/Restriction fragment length polymorphism (RFLP) typing of human and poultry Campylobacter jejuni strains. Letters in applied microbiology, Oxford, v. 34, p. 354-358, 2002.

77. SU, Y. C. E WONG, A. C. L. Current perspectives on detection of staphylococcal enterotoxins. Journal of Food Protection, v.60, n.2, p.195-202, 1997.

78. SYNNOTT, M.B.; BRINDLEY, M.; GRAY, J.; DAWSON, J.K. An outbreak of Salmonella Agona infection associated with precooked turkey meat. Communicable Disease and Public Health, v.1, p.176-179. 1998. 
Silva et al., Revista Brasileira de Higiene e Sanidade Animal (v.11, n.3) p. 338 - 353, jul - set (2017)

of the International Dairy Federation,

Brussels,v.345, p.15-18, 2001.

79. VALERO, A.; RODRÍGUEZ, M.Y.; POSADAIZQUIERDO, G.D.; PÉREZ-RODRÍGUEZ， F.; CARRASCO, E.; GARCÍA-GIMENO, R.M. Risk Factors Influencing Microbial Contamination in Food Service Centers. In Significance, Prevention and Control of Food Related Diseases, 2016.

80. VANZO, S. P.; AZEVEDO, R. V. P. Revista Higiene Alimentar, São Paulo, v.17, n.104/105, p.114-123, 2003.

81. VON RUCKERT, D.A.S.; PINTO, P.S.A.; SANTOS, B.M.; MOREIRA, M.A.S.; RODRIGUES, A.C.A.; Pontos críticos de controle de Salmonella spp. no abate de frangos. Arquivo Brasileiro de Medicina Veterinária e Zootecnia, v.61, n.2, p.326330, 2009.

82. UBABEF, 2016. Disponível em < http://abpabr.com.br/storage/files/versao_final_para_envio_digit al_1925a_final_abpa_relatorio_anual_2016_portugue s_web1.pdf > Acesso em 03 de Maio de 2017.

83. UNITED STATES DEPARTMENT OF AGRICULTURE (USDA). FOOD SAFETY AND INSPECTION SERVICE STRATEGIC PLAN 2017-2021. Oct. 2016. Disponível em: <https://www.fsis.usda.gov/wps/wcm/connect/317d1 4d6-1759-448e-941a-de3cbff289e5/Strategic-Plan2017-2021.pdf?MOD=AJPERES >.

84. WAGENAAR, J.A.; FRENCH, N.P.; HAVELAAR, A.H. Preventing Campylobacter at the source: why is it so difficult?. Clinical infectious diseases, v.57, n.11, p.1600-1606, 2013.

85. WORLD HEALTH ORGANIZATION (WHO). Global principles for the containment of antimicrobial resistance in animals intended for food. 2000 Disponível em: <http://whqlibdoc.who.int/hq/2000/WHO_CDS_CSR _APH_2000.4.pdf>.

86. ZHAO, C.; GE, B.; DE VILLENA, J.; SUDLER, R.; YEH, E.; ZHAO, S.; MENG, J. Prevalence of Campylobacter spp., Escherichia coli, and Salmonella serovars in retail chicken, turkey, pork, and beef from the Greater Washington, DC, area. Applied and environmental microbiology, 67(12), 5431-5436. 2001.

87. ZECCONI, A.; HAHN, G. Staphylococcus aureus in raw milk and human health risk. Bulletin 